\title{
Less Is More: An Implementation of an Extensive Reading Program in an English Proficiency Course in the Sultanate of Oman
}

\author{
Syerina Syahrin ${ }^{1}$ \\ ${ }^{1}$ English Language and Literature Department, College of Arts and Applied Sciences, Dhofar University, \\ Sultanate of Oman \\ Correspondence: Syerina Syahrin, English Language and Literature Department, College of Arts and Applied \\ Sciences, Dhofar University, 211 Salalah, Sultanate of Oman. E-mail: sysyahrin@du.edu.om
}

Received: July 29, $2020 \quad$ Accepted: September 2, $2020 \quad$ Online Published: September 7, 2020

doi:10.5539/ijel.v10n6p171 URL: https://doi.org/10.5539/ijel.v10n6p171

\begin{abstract}
This paper reports the implementation of an Extensive Reading (ER) program in an English proficiency course at a higher education institution in the Sultanate of Oman. The implemented ER program for this study is titled, "Less $i s$ More" utilizing a readily available website, Voice of America (VOA) Learning English. Data was gathered from undergraduate students of Omani nationality enrolled in an English proficiency course for Spring 2020/2021 semester during the Covid-19. The findings of the study were gathered from multiple sources namely reading speed, comparison of pretest and posttest scores, semi-structured interviews, online focus group discussion, and the course instructor's reflection of the implementation of the ER program. The backgrounds of the students were considered too. The findings revealed that the average students' reading speed was consistent at $100 \mathrm{wpm}$ (word-per-minute) throughout the ER program. There was a positive outcome on the students' posttest scores and a significant correlation between the number of articles the students read to their posttest scores. The data from the qualitative inquiry provided an insight into the use of modified texts to encourage more reading. Although the research did not investigate the best practices for an ER in the context of an English proficiency classroom in Oman, it showed how an ER can be implemented online given the circumstances of the Covid-19 pandemic.
\end{abstract}

Keywords: extensive reading, ESL, Oman, online, reading

\section{Introduction}

Lituanas, Jacobs, and Renandya (2001) observed that one of the ways to improve a learner's second language proficiency, especially in an environment where the language is hardly heard or spoken, is through reading. This study argues that it is essential for language proficiency course instructors to offer learners the opportunity to become skilled readers. In the case of multilingual societies such as the Sultanate of Oman, this means becoming skilled English language readers. This skill represents learners' futures so that they are able to negotiate careers and to seek advancement in modern societies, an important aspect of Oman Vision 2040.

This investigation stems from the studies proposed by several English as Second Language (ESL) research, such as the works of Day and Bamford (1998), Nation (1997), Krashen (2009), and a study conducted in Oman by Fawzia and Salwa (2016) that Extensive Reading (ER) is invaluable in improving English language proficiency. This conviction derives from the assumption that ER enables learners to acquire language input (Krashen, 2009) through the imitation of the process of real-life- reading (Arnold, 2009) just as how we learn to read in our first language (Susser \& Rob, 1990).

Many ESL researchers believe that through "prolonged practice" (Nell, 1988, p. 84) or "learning to read by reading" (Smith, 1985, p. 88) with the right "stance" (Rosenblatt, 2005), learners would be able to able to read fluently. This helps in promoting lifelong readers and, in addressing the root problem in the Sultanate of Oman, the absence of reading culture which in turn, affects their proficiency in the English language.

Previous investigations reported that the English proficiency among the school graduates in the Sultanate of Oman are limited and are not sufficient in meeting the requirement of the tertiary education and the demands of the workplace (Al-Mahrooqi \& Tuzlukova, 2014), and this is a cause for concern to English proficiency course instructors, policymakers and the wider community. A recent report by the Education First (EF) English 
Proficiency Index revealed that Oman ranked 92nd in the 100 countries participated (English First English Proficiency Index, n.d.; "English proficiency in Mideast lowest in the world", 2019). The IELTS test statistics report in 2018 indicated that the overall IELTS scores for Oman are 5.22 (IELTS, n.d.). The details of the IELTS test statistics report for 2018 are tabulated in Table 1.

Table 1. IELTS test statistics for 2018

\begin{tabular}{ll}
\hline IELTS Test & Scores \\
\hline Reading & 4.93 \\
Writing & 5.00 \\
Listening & 5.14 \\
Speaking & 5.55 \\
Overall & 5.22 \\
\hline
\end{tabular}

The data provided in Table 1 is adapted from IELTS Performance for Test Takers (n.d.), retrieved from https://www.ielts.org/teaching-and-research/test-taker-performance.

The IELTS test statistics for Oman in 2018 revealed that the lowest performance is on the reading skills. The data appears to echo Fawzia and Salwa's (2016) report that states "the frequency of reading amongst students is very low as $53 \%$ of the students read only once a semester and they often read the same type of genre" (p. 1). This paper argues that by encouraging students to simply read more, particularly texts that are similar in the cognitive processing (Bax, 2013) to IELTS reading passages, it increases the amount of input and exposure to the English language, and in turn, aids the development of the language (Ellis, 2010).

\subsection{Research Objectives}

The paper reports the findings of an online ER program in the context of an English proficiency classroom at a higher learning institution in the Sultanate of Oman. The quantitative and qualitative data of the findings were gathered to address the objectives of the study, namely:

1) To report the reading speed for each student/participant of the study (Arabic / Jibali-native speakers reading modified English texts online)

2) To evaluate if there is a significant improvement in the students' IELTS Reading scores, before (pre-test) and after (post-test) ER program

3) To seek understanding of the students' perspectives of the use of online modified English texts and online ER program

4) To seek understanding of the course instructor's perspectives on the implementation of the online ER program

\subsection{Literature Review}

This section of the paper discusses the key notions relevant to the study which includes a review of ER and the ER programs, issues, and debates on ER and Voice of America (VOA) Learning English.

\section{Extensive Reading (ER)}

Although many ESL teachers hold the belief that the ER helps to build L2 proficiency, particularly L2 reading skills, previous studies seem to have different opinions on what ER means. While some ER experts encourage the use of journals in ER programs, some experts believe that no tasks should be made accountable to the learners' reading. According to Day and Bamford (1998), the term ER is first coined by Palmer back in the early 1900s. ER is viewed as a replication of real-life reading in the sense that reading is focused on meaning and general comprehension. The goal is enjoyment and/or to gain information. Learners select their own texts which they read with minimal help from the dictionary (Arnold, 2009). One of the characteristics of ER suggested by Bamford and Day (1998) is to have learners read texts which are within their linguistic ability. This result in the publication of different level of graded readers and modified texts. The other characteristic of ER that Bamford and Day (1998) suggested is to have "students read as much as possible" (pp. 7-8). Here lies one of the issues within the ER: how much is "as much as possible"? The common assumption made is that it means large quantities of hours, books, and the length of texts. These range from 7 sessions twice a week for 75 minutes (Arnold, 2009), to 75-pages-a-week (Welch, 1997), to 20-minutes-a-day over 12-week English for Academic Purpose course (Macalister, 2008). 


\section{ER Programmes}

Over the years, ER program has taken several other names such as Reading-for-Pleasure, Voluntary Reading, Free-Voluntary Reading (FVR), Uninterrupted Sustained Silent Reading (USSR), Drop Everything and Read (DEAR), and Silent Uninterrupted Reading for Fun (SURF), and the Book Flood program (Elley \& Mangubhai, 1983). ER program in Oman was introduced by the Ministry of Education of Oman for grade five pupils upwards and provided the school teachers with a framework to carry out the program (Fawzia \& Salwa, 2016). Krashen (2009), one of the strongest promoters of the incorporation of ER in second and foreign language learning, developed a theoretical model of L2 teaching. According to Krashen (2009), to have a successful second language classroom, the teaching program needed to include two major components: acquisition and learning. Krashen (2009) argues that L2 classrooms often put too strong an emphasis on the 'learning' aspect of the language and disregard the 'acquisition' process of the language to take place. He lists ER as one of the means to enable students to acquire L2 and this should be part of the 'obligatory' L2 teaching program. Other promoters of ER argue that if ER is carried out appropriately, not only will the program help students to read in L2, but it will also help them to enjoy reading (Day \& Bamford, 1998). The theoretical assumption made by the promoters is that the ER program provides L2 learners with sufficient information to enable 'intake' to take place in acquiring L2. Such 'intake' is essential as it builds learner autonomy in language learning and enables them to enjoy reading.

The United States National Reading Panel (NRP) report in 2000 stirred the controversy on the use of ER in L2 learning. The report found no evidence to support claims that ER practices lead to reading comprehension improvement. The report explained that direct experimental evidence for the effectiveness of ER did not occur in their research. Correlational studies on ER, on the other hand, support the claims that ER has a major impact on reading comprehension, and it was argued that other factors may have contributed to the results of the studies making it hard to single out the idea that reading extensively would make better readers (Cipielewski \& Stanovich, 1992). NRP (2000) concluded that they were not able to find any convincing gains attributed to ER and therefore, they were not able to make a positive endorsement of ER programs in the United States. The following part of the paper discusses further the issues that have been raised against the effectiveness of ER.

\section{Issues and debates in ER}

\section{Modified texts: Are they better than authentic texts?}

One of the common issues highlighted in ER studies is the use of modified texts. One of the characteristics of ER is to present the readers with "reading materials [that] are well within the linguistic competence of the students in terms of vocabulary and grammar" (Day \& Bamford, 1998, pp. 7-8). That is to say, ER encourages the readers to select easy reading materials. Nation (2001) defines 'easy' as when one recognizes $98 \%$ of all the words in the text. Seidlhofer (2004) defines 'easy' as reduced, simplified and 'minimalist' forms of English as an additional language for the majority of the people within the pedagogy of English as a lingua franca (ELF). The theoretical assumption for the use of modified texts in ER programs is the belief that reading can be learned more effectively through the use of easy texts instead of through laborious decoding and translating difficult (authentic) texts which are beyond learners' ability (Bassett, 2005). Critics argue that modified texts do not expose readers to the actual use of the language, and thus gives language learners a false impression of the language learned. Day and Bamford (2002) commented that graded reader texts have been characterized as "stilted, unnatural, unreal" (p. 56).

Some reading experts argue that modified texts are often written in poor English or loosely-written content (Davison, 1986; Wallace, 1988) and that the simplification of the texts removes the richness and the subtlety of the original texts (Crossley, Louwerse, McCarthy, \& McNamara, 2007), leaving the writing more difficult to be understood than the original texts. This accusation towards modified texts is backed by empirical investigations that found some modifications, such in the case of adding narrative elements to an expository text, can make a text more difficult to read (Nagabhand, Nation, \& Franken, 1993). Simensen (1990) found that modified texts, being reduced semantically, can lead to ambiguities and various interpretations to the reader.

\section{Variety and quantity of ER texts: How much is enough?}

Day and Bamford (2002) recommend an ER library consists of a wide range of text types and genres to enable students to choose freely the texts they enjoy most. Nuttall (1996) suggests that the library should have at least twice as many books and recommends four times as many as the number of students for the sake of adequate circulation of reading materials. Previous researchers have found that a reader's familiarity with the story-telling conventions aids their comprehension of the texts, as in the case of Johnson's (1981) study of University Iranian EFL students on Persian versus American simplified folklore. This finding is crucial as it helps to suggest the 
kinds of ER texts that should be published. However, Marianne (2009) pointed out that there has been little research investigating the effects of different literary styles of writing on the reading experience or the meanings made of texts.

Chun (2006) noted the lack of research on online extensive reading while Walz (2001) advocated the use of the Internet for ER because it covers a wide variety of topics and it allows students to find texts of interest to them. Arnold (2009) and Sun (2003) carried out ER online reading programs and found positive 'gains' among the participants. In Malaysia, Shari (2008) observed that 14- and 16-year-old male teenagers in Malaysia were de-motivated because the materials available in the library did not reflect their diverse interests.

\section{The teacher's role in ER}

It is a common misconception that because ER allows the students to make their own choice of reading materials, students determine the reading plan and progress independently. Students are left on their own to decide the 'right' choices. Zhang (2009) suggested that teachers have to play the role of facilitator, offering the essential reading strategy and giving guidance in gaining information and language knowledge. Rosenblatt (1986) suggested that teachers need to teach the learners the difference between efferent reading and aesthetic reading, and guide them to make the right choices for their reading. However, Claridge (2011) observed that teachers often interpret ER in classroom teaching aims to exploit the texts in teaching grammar and content. She further explains that such perception is motivated by the perception that all of their teachings will be accountable. Furthermore, she argues that teachers often decide what kinds of graded readers need to be published. This, in turn, leads to other problems, such as the production of low-level graded readers because the texts are not of high demand.

\section{Voice of America (VOA) Learning English (https://learningenglish.voanews.com/2}

VOA Learning English is a special program by Voice of America, the U.S government broadcasting agency, for English teaching materials. VOA Learning English, formerly known as VOA Special English, was launched in 1959 as an English newscast. In recent years, VOA Learning English provides digital content, television, and radio, application and is accessible on the mobile phone, satellite, cable, FM, and MW as well as social media (VOA Learning English, n.d.). Templer (2009) describes VOA Learning English as "a unique multimodal resource for a graded, simplified form of ELF based on 1,500-word families as core lexis" (p. 194). Templer's (2009) detailed analysis of VOA Learning English features are listed as follows:

A. It is readily available online (https://learningenglish.voanews.com/) and on shortwave radio for free.

B. The materials are based on a 1,500 word-family vocabulary, with simpler syntax, and very few idioms

C. The newscasts and reports utilize short sentences averaging 14 words.

D. The speed of the broadcasting is at 90 words per minute, which is about one-third slower than the normal broadcast speed

E. The materials are available as print texts and with audio [and/or video] and many can be downloaded as MP3 files

F. The materials cover a wide range of topics from education, history, American biography, and music, to health, science, economics, and development.

G. The genre is multimodal, combining text, image, and sound

Since 2014, VOA has updated the content into 14 categories of audio programs and 9 categories of video programs. The materials are accessible in the archive online which provides a huge library for modified English texts that are largely nonfiction with a kind of "ESP-Lite" (Templer, 2009, p. 202). These features offered by VOA Learning English builds the case for this study as it aims to provide the students with an avenue of the online library of modified texts that the students can access on their own. Additionally, the students who participated in the ER program are enrolled in an English proficiency course that prepares them for the IELTS examinations. The materials available on the VOA Learning English that are based on the 1,500-word family vocabulary and are nonfiction would conceptually facilitate the students in becoming familiar with IELTS reading texts. Eldridge and Neufeld (2009) discovered that a threshold of 1,650 of the most common words in English is the key base level for students to achieve a 5.5 score in the IELTS examination. The digital content available on VOA Learning English is not only in print text but it includes a combination of other modes. Previous studies suggested that when a print text includes visual meanings such as images, page layouts, screen formats, audio meanings such as music and sound effects, gestural meanings such as body language and sensuality, spatial meanings such as the meanings of environmental spaces and architectural spaces and 
multimodal meanings (New London Group, 1996) it aids the students' meaning-making process (Claridge, 2011) and they perform better on the transfer of knowledge and retention of words (Neuman, 2009).

The key notions and the issues that were addressed in this section build a case for an approach to investigation that requires a mixture of quantitative and qualitative inquiry. Because the study is situated in the context of an English proficiency course in Oman that prepares the students for the IELTS examinations, the quantitative inquiry provides statistical data for the specific course. The qualitative inquiry, on the other hand, is aimed to gather open-ended perspectives and "thick descriptions" (Bogdan \& Biklen, 2007, p. 30) of the students' experience with the ER program.

\section{Method}

The ER program is titled, "Less is More". It is a metaphoric phrase used to express the effectiveness of a minimalist approach to encourage more reading. The term "less" is used to suggest the use of simplified texts based on a 1,500 word-family. Less is More was carried out with a group of undergraduate students enrolled in an English proficiency course at a higher education institution in the Sultanate of Oman during the Covid-19. During the period of investigation, the majority of higher learning institutions in Oman rapidly transitioned from the face-to-face classroom to online learning systems ("Oman suspends schools, universities from Sunday", 2020).

\subsection{Research Design}

The study aims to explore the experiences of the students in an ER program and to identify if it has significant effects on their reading speed and their IELTS Reading scores. Paramount to achieving this was an approach that empowers the students to select their own texts on VOA Learning English with no tasks made accountable to them. The goal is to replicate real-life reading enjoyment and/or to gain information, which Rosenblatt refers to this as the "aesthetic stance" (1986, p. 124). The statistical data gathered from the study is aimed to provide an evaluation for the incorporation of the ER program to the English proficiency course.

\subsection{Participants of the Study}

The study uses a specific category of case-purposive sampling which are: 1) Omani nationality, 2) students enrolled in an English proficiency course. All of the students $(n=72)$ enrolled in the course are invited to participate in the "Less is More" program. Only students who submitted their consent and actively participated in the ER program are included in the findings of the study.

\subsection{Data Collection Procedures}

\subsubsection{Measures: Reading Speed and IELTS Reading Scores}

The students' self-recorded and reported their reading speed to the course instructor. The speed of students' reading is important in a class that helps prepare them for the IELTS examination. An actual IELTS Reading examination consists of 3 passages and examination candidates are allowed an hour to answer the questions. The IELTS reading passages typically range between 700-1,000 word-count. The British Council recommends examination candidates to spend 20 minutes for each passage (IELTS, n.d.). The participants of the study were given three separate passages that were adapted from IELTS Practice Tests (May, 2004) on Week 1 of the ER program. The students' scores for each of the passages were recorded and tabulated as the pre-test. On Week 10 of the ER program, the students were given similar reading passages as the pre-test. The students' performance on Week 10 was recorded and tabulated as a post-test.

\subsubsection{Measures: Semi-Structured Interviews and Focus-Group Discussion}

The semi-structured interviews and the online focus-group discussion were utilized to provide data that are "thick descriptions that are vivid, nested in a real context" (Miles \& Huberman, 1994, p. 10). The findings from the qualitative inquiry provided information about the students' backgrounds, their perceptions of the ER program as well as the materials on VOA Learning English. This study revealed how through online focus-group discussion, the students facilitated their peers by adding more information, allowed further probing, and helping with the flow of conversation.

\section{Results and Discussion}

This section presents the summary of the findings, namely: reading speed, pre-test and post-test IELTS Reading scores, feedback from the participants, and course instructor's reflection. Each of these will be described in turns.

\subsection{Reading Speed}

The findings for the students' reading speed were gathered from 3 participants. The students shared the reading 
links and the time they spend reading the articles through Google's shared document. The data for the students' background was gathered through individual semi-structured interviews on video/audio conferencing (Zoom) as well as email.

\section{Student 1}

Background of the Student. Student 1 is a 22-year old female Omani. The student studied English for 12 years through Oman public schooling system. This is followed by six months of learning English at the University's Foundation program. Upon completing her Foundation program, the student was admitted to an undergraduate course. The University requires the student to take five English proficiency courses as part of the undergraduate program. Student 1 had taken 4 of the English proficiency courses before enrolling in the English proficiency course for the Spring 2020/21 semester. The student's MGPA score is at 89.9 and is highly motivated to do well in the course. The student speaks Arabic at home with her family members, and with her peers. In the classroom, the student speaks in English "as much as I can" with her peers during group discussion and with her teachers. Student 1 has a sister studying in the U.K., and she aspires to pursue her postgraduate education at the U.K. Student 1 prefers "following" social media account of influencers and celebrities from the U.S. and the U.K. than those of Arabic-speaking ones. Table 2 shows the record of Student 1's reading speed for the materials on VOA Learning English, ranging from 600 to 1,000 word-count for 34 texts.

Table 2. Reading speed student 1

\begin{tabular}{llll}
\hline Word count & N & Average (mean) & Standard Deviation \\
\hline $\mathbf{9 0 0 - 1 , 0 0 0}$ words & 10 & 9.357 & 0.074333333 \\
$\mathbf{8 0 0 - 8 9 9}$ words & 10 & 8.294 & 0.021333333 \\
$\mathbf{7 0 0 - 7 9 9}$ words & 10 & 7.045 & 0.015 \\
$\mathbf{6 0 0 - 6 9 9}$ words & 4 & 6.305 & 0.020207259 \\
\hline
\end{tabular}

On average, the student read 3 texts a week for 10 weeks of the ER program, at about 100 words-per-minute (wpm).

\section{Student 2}

Background of the Student. Student 2 is a 48 -year old female Omani. Student 2 is an adult student and an employee of a company. Student 2 studies part-time at the University and is a single mother. Her motivation for education is to have a better-paid salary and to inspire her daughters to pursue higher education. Student 2 studied English through formal schooling, however, she remarked, "I forgot everything already' because the English language is not used at her workplace, nor home. Student 2 completed three levels of the University's foundation program and three English skills-based classes before enrolling in the English proficiency course for the Spring 2020/21 semester. Table 3 shows the record of Student 2's reading speed for the materials on VOA Learning English, ranging from 300 to 1,000 word-count for 72 texts.

Table 3. Reading speed student 2

\begin{tabular}{llll}
\hline Word count & N & Average (mean) & SD \\
\hline $\mathbf{9 0 0}-\mathbf{1 , 0 0 0}$ words & 12 & 9.623333333 & 0.222113 \\
$\mathbf{8 0 0 - 8 9 9}$ words & 12 & 8.4425 & 0.389955 \\
$\mathbf{7 0 0 - 7 9 9}$ words & 12 & 7.12 & 0.661315 \\
$\mathbf{6 0 0 - 6 9 9}$ words & 12 & 6.339166667 & 0.983932 \\
$\mathbf{5 0 0 - 5 9 9}$ words & 12 & 6.075833333 & 1.092476 \\
$\mathbf{3 0 0}-\mathbf{4 9 9}$ words & 12 & 3.648333333 & 1.822134 \\
\hline
\end{tabular}

On average, the student read 7 texts a week for 10 weeks of the ER program, at about 100 words-per-minute (wpm).

\section{Student 3}

Background of the Student. Student 3 is a 36-year-old male Omani. Student 3 is also an adult student and works in the public sector. Student 3 plays an important role in the workplace while pursuing his education. He is the father of three children. He finds time-management, and work-study-life balance as "very challenging". Student 3 had experienced IELTS examination. He was exempted from the English courses at the Foundation program. 
Upon admission into the undergraduate program, he was exempted from two of the English proficiency courses. Student 3 is highly motivated to do well for the course, uses English at the workplace with his colleagues from other nationalities, and aims to be proficient at the language. He described his motivation to do well in English "people will respect me more and more". Table 4 shows the record of Student 3's reading speed for the materials on VOA Learning English, ranging from 500 to 1,000 word-count for 29 texts.

Table 4. Reading speed student 3

\begin{tabular}{llll}
\hline Word count & $\mathbf{n}$ & Average (mean) & Standard Deviation \\
\hline $\mathbf{9 0 0}-\mathbf{1 , 0 0 0}$ words & 10 & 8.516 & 0.011333333 \\
$\mathbf{8 0 0 - 8 9 9}$ words & 4 & 7.3225 & 0.540399852 \\
$\mathbf{6 0 0 - 6 9 9}$ words & 5 & 6.16 & 1.228 \\
$\mathbf{5 0 0 - 5 9 9}$ words & 10 & 5.509 & 1.005333333 \\
\hline
\end{tabular}

On average, the student read 3 texts a week for 10 weeks of the ER program, at about 100 words-per-minute (wpm).

\subsection{IELTS Reading Score}

The findings for the students' IELTS Reading Score was gathered from $n=15$ participants. The number of articles that the students read was recorded too. Unlike the actual IELTS examination, the IELTS Reading administered for both pretest and posttest contains 30 questions. Each correct answer is awarded one mark. To test if there is a significant improvement in the students' scores from the pretest to the posttest, Paired Samples T-Test is applied. The data were analyzed with IBM SPSS 26.

Table 5. Paired samples test pretest and posttest scores

\begin{tabular}{|c|c|c|c|c|c|c|c|c|c|}
\hline & & \multicolumn{5}{|c|}{ Paired Differences } & \multirow[t]{3}{*}{$\mathrm{t}$} & \multirow[t]{3}{*}{ df } & \multirow{3}{*}{$\begin{array}{l}\text { Sig. } \\
\text { (2-tailed) }\end{array}$} \\
\hline & & \multirow[t]{2}{*}{ Mean } & \multirow[t]{2}{*}{$\begin{array}{l}\text { Std. } \\
\text { Deviation }\end{array}$} & \multirow[t]{2}{*}{$\begin{array}{l}\text { Std. Error } \\
\text { Mean }\end{array}$} & \multicolumn{2}{|c|}{$\begin{array}{l}95 \% \text { Confidence Interval of } \\
\text { the Difference }\end{array}$} & & & \\
\hline & & & & & Lower & Upper & & & \\
\hline Pair 1 & Pretest A - Posttest A & -1.93333 & 1.66762 & .43058 & -2.85683 & -1.00984 & -4.490 & 14 & .001 \\
\hline Pair 2 & Pretest B - Posttest B & -2.46667 & .91548 & .23637 & -2.97364 & -1.95969 & -10.435 & 14 & .000 \\
\hline Pair 3 & Pretest C - Posttest C & -2.73333 & 1.27988 & .33046 & -3.44211 & -2.02456 & -8.271 & 14 & .000 \\
\hline
\end{tabular}

Table 5 revealed that at $p$-value $(<0.05)$, there was a significant improvement in the participants' posttest scores, thus rejecting the null hypothesis that there is no significant improvement in the students' posttest scores after the ER program. This finding is consistent with the report by Syahro $(2009,2011)$ that found significant improvement in the participants IELTS mock examinations by incorporating VOA materials into the classroom teaching and learning.

To test if there is a correlation between the number of texts the students read to the total score of the students' post-test, the Pearson Correlation Coefficient is applied. Table 6 illustrates the data.

Table 6. Correlations the number of articles and posttest scores

\begin{tabular}{llll}
\hline & & Posttest Score & Number of Articles \\
\hline Posttest Score & Pearson Correlation & 1 & $.893^{* *}$ \\
& Sig. (2-tailed) & & .000 \\
& N & 15 & 15 \\
Number of Articles & Pearson Correlation & $.893^{* *}$ & 1 \\
& Sig. (2-tailed) & .000 & \\
& N & 15 & 15 \\
\hline
\end{tabular}

Note. $* *$. Correlation is significant at the 0.01 level (2-tailed).

The Pearson correlation coefficient for the number of articles and posttest scores is .893 , which is significant $(p<.001$ for a two-tailed test).

3.3 Students' Perspectives of the ER and VOA Learning English 
The focus-group discussion was held on Week 10 of the ER program through audio/video conference (Big Blue Button). The students provided feedback through verbal responses (audio) and written responses (chats). The discussion activity was guided by these semi-structured questions:
A. What do you like/dislike about the articles on VOA Learning English?
B. Would you read the articles on your own after the ER program?
C. What do you like/dislike about the ER Less is More program?

The verbal responses and written chats were recorded and viewed closely to identify a suitable frame for analysis and where necessary, they were grammatically adjusted. The broad domains that were derived from the questions were coded as follows: readability, multimodality, vocabulary, learning activities, ER, and motivation. Each of these is described in turns.

\section{Readability}

The majority of the students reported that the texts are easy to be read. One of the students wrote, "easier than the ELTS textbook", while another student added, "now I can read the news in English". The student explained that he had been encouraged to read the news in English by his English teachers, however, he used to find the news articles difficult to be understood. As he enjoyed following the news on sports, he resulted to watching videos on YouTube in English instead. For the majority of the time, he reads the news in Arabic. The students' positive feedback on the readability and easiness of the texts reflect Day and Bamford's (1998) recommendations for ER. Day and Bamford (1998) suggested that for an ER to be successful is to present the readers with, "reading materials [that] are well within the linguistic competence of the students in terms of vocabulary and grammar" (pp.7-8).

\section{Multimodality}

The majority of the students attributed the slow delivery of the broadcasting, video, and audio files on VOA Learning English aided their understanding of the text. One of the students added, "I can stop, pause, and listen again". In an English language teaching classroom, Thomson and Mcllnay (2009) found positive outcomes through the use of visual texts on the students' increased participation, improved reading comprehension, motivation, and confidence in reading.

\section{Vocabulary}

The majority of the students reported that reading the articles helped them in discovering new words, which otherwise they may have not encountered. The students explained that having a vocabulary list at the end of the text (for the majority of the articles on VOA Learning English), aided their reading comprehension skills.

\section{Learning activities}

There were mixed responses to the learning activities. A number of the articles on VOA Learning English include quizzes that test the students' understanding of the text and in-context vocabulary. While two students find it useful, the other students did not enjoy and chose not to do those activities. One of the students wrote in the group chat, "it's like an exam [...] I don't like exams", while another student wrote, "[the quizzes] take time. We already have many quizzes to do". The students' feedback reflects Rosenblatt's (1986) "aesthetic stance" (p. 124) in which no tasks should be made accountable to enable the students to enjoy reading. This finding is inconsistent with Elley's (1991) report that attributes one of the factors for successful ER is for teachers to integrate learning activities with the students. For the students in this particular study, accounting a task on them is seen as a burden and that it takes away the aesthetic stance of reading.

\section{Incorporation of the ER program in the English proficiency course}

The students gave mixed responses to the incorporation of the ER program in the English proficiency course. While 7 of the students find the program useful and had helped them to read more in English, the other students wrote that "it's difficult, teacher [...], we don't have good internet connection in the mountain". Another student added that because the ER and the activities related to the ER program were not accounted for her final examination grade, she did not find the ER program useful. Regarding the student's comment on the internet connection, access to the internet and speed of the internet are well-documented issues in Oman. Previous investigations reported that these are the factors that hinder online education. Al-Musawi (2002), wrote, "Oman Telecommunication Company's Internet service has struggled from time to time as demands constantly outstripped capacity" (p. 2). Al-Musalmy however reported, "telecommunication providers are already improving the facilities in Oman, in view of the COVID-19 experience" ("COVID-19 creates a positive path for online education", 2020, para. 8). Regarding the student's comment on the relevance of participating in ER to the 
final examination grades, this finding is also reflected in the students' motivation to read and the course instructor's reflection, which will be described in the next section.

\section{Motivation to read}

There was no clear feedback on the students' motivation to read the articles on VOA Learning English after the ER program as the majority of the students wrote, "Insya Allah" (if God wills). One of the students wrote, "I will read more when I sit for the IELTS examination". The student's comment revealed the student's motivation to read is directed to doing well in the examination. In another study on the implementation of ER in the Sultanate of Oman, Fawzia and Salwa (2016) reported,

Some teachers said that the students are unwilling to read extensively while others pointed out that the students ask others to do it for them. A couple of teachers talked about the negative attitudes of students and that they see extensive reading as a heavy burden. Some believed that it worked well with the high achieving students only (p. 103).

\subsection{Course Instructor's Reflection}

The course instructor used memoing to record quotes or actions by the students participating in the ER program. The notes also include the course instructor's subjective reflections, which Berg (2007) explains, "self-reflective opportunity to make personal observations and comments" (p. 199). The notes are essential for a nuanced understanding of the experiences of the students and the course instructor in the implementation of the ER program. The broad domains that were derived from the notes were coded into two categories: students' motivation to read and the role of the teacher.

\section{Students' motivation to read}

Out of the 72 students invited to participate in the ER program, only 15 students submitted their consent $(20.8 \%$ of the students), while only 3 out of the 15 students actively participated in the ER throughout the 10 weeks (4.2\%). Unless the reading has direct consequences to their course grades, the students do not want to read the texts. The common questions from the students were, "Is this in the exam?", "are there marks for this?". The students who actively participated and those who were somewhat committed to reading are those who are already fluent in English and are intrinsically motivated. This finding is consistent with Fawzia and Salwa's (2016) report that the ER program worked with high achieving students. It also reflects Elley (1991) recommendation that one of the factors that attribute the success of an ER program is the high intrinsic motivation among the students. The course instructor's notes echo Al-Ani's (2017) report that revealed the examination-oriented schooling system and practices dominated the educational framework in Oman. Al-Mahrooqi (2012) uncovered one of the factors that attribute to low proficiency in English in Oman, as "there is not enough focus on reading as no time is specified for this skill” (p. 266).

\section{Teacher's Role in an ER}

It is important to note that the term teacher and course instructor is used interchangeably in this paper. Previous investigations suggested that the teacher plays a vital role to inculcate the students' interest in reading (Krishna et al., 2009; Al-Mahrooqi, 2012; Fawzia \& Salwa, 2016). The students relied heavily on the course instructor on modeling the reading practices. Every week throughout the ER program, the course instructor shared her own reading links from VOA Learning English with the students on the Google shared document. The course instructor listed the recommended texts for the students to explore and read on their own. Notification of reminder was also sent on the e-learning platform. Without the course instructor's weekly initiation, there was no initiative from the students to share their own reading links without being asked to. The responses from the students included, "I was busy" and "I forgot" which threads in their motivation to reading.

\section{Conclusion}

Although the study focused on a small sample of undergraduate students in Oman, it has important implications for research and pedagogical practice for ESL classrooms in Oman. First, while the statistical analysis did not indicate an improved reading speed over the 10 weeks, it showed that the students were consistent at their reading speed of an average $100 \mathrm{wpm}$. The data showed a positive outcome on the students' IELTS reading score and a significant correlation between the number of texts the students read to their posttest scores. The statistical findings provided substantial evidence for the incorporation of online ER in English proficiency courses in Oman to be considered. In lieu of the government's initiative towards distance learning, the implementation of online ER is timely. Second, the responses from the quantitative and qualitative inquiry built a case for the use of modified and simplified texts in the language classroom to encourage more reading. As course instructors of an ESL classroom, not only we play the role to model good reading practices, we have to be resourceful in 
providing the students with an avenue to explore a variety of reading materials. Finally, to motivate and to establish a reading culture in Oman that goes beyond the need for passing examinations, a nationwide reading motivation campaign is required. It also requires cooperation among the policymakers, educational institutions, teachers, parents, and the wider community to draw links between the benefits of ER to life-long learning, an important aspect of Oman Vision 2040.

\section{Acknowledgments}

Sincere thanks must go to Professor Bill Templer, Dr. Carolyn Tait, and Dr. John Dickie for their support, guidance, and counseling that led to this research and the write-up of the paper.

\section{References}

Al Musawi, A. (2002). Issues and prospects of e-learning in Oman. In EdMedia+ Innovate Learning (pp. 17-18). Association for the Advancement of Computing in Education (AACE).

Al-Ani, W. (2017). Alternative education needs in Oman: accommodating learning diversity and meeting market demand. International Journal of Adolescence and Youth, 22(3), 322-336. https://doi.org/10.1080/02673843.2016.1179204

Al-Mahrooqi, R. (2012). A student perspective on low English proficiency in Oman. International Education Studies, 5(6), 263-271. https://doi.org/10.5539/ies.v5n6p263

Al-Mahrooqi, R., \& Tuzlukova, V. (2014). English communication skills and employability in the Arabian Gulf: The case of Oman. Pertanika Journal of Social Sciences \& Humanities, 22(2).

Arnold, N. (2009). Online Extensive Reading for Advanced Foreign Language Learners: An Evaluation Study. Foreign Language Annals, 42(2), 340-366. https://doi.org/10.1111/j.1944-9720.2009.01024.x

Bassett, J. (2005). What makes a good reader? Oxford University Press ELT Teacher's Club. Retrieved from http://www.oup.com/elt/teachersclub/articles/reader?view=Print\&cc $=\mathrm{gb}$

Bax, S. (2013). Readers' cognitive processes during IELTS reading tests: Evidence from eye tracking. https://doi.org/10.1177/0265532212473244

Berg, B. L. (2007). Qualitative research methods for the social sciences (6th ed). Boston, MA: Allyn and Bacon.

Bogdan, R. C., \& Biklen, S. K. (2007). Research for education: An introduction to theories and methods. New York: Pearson.

Chun, D. M. (2006). CALL technologies for L2 reading. In L. Ducate \& N. Arnold (Eds.), Calling on CALL: From theory and research to new directions in foreign language teaching (pp. 69-98). San Marcos, Texas: CALICO Publications. Retrieved from http://lt.msu.edu/vol11num1/review3/default.html

Cipielewski, J., \& Stanovich, K. E. (1992). Predicting growth in reading ability from children's exposure to print. Journal of Experimental Child Psychology, 54, 74-89. https://doi.org/10.1016/0022-0965(92)90018-2

Claridge, G. M. H. (2011). What Makes a Good Graded Reader: Engaging with Graded Readers in the Context of Extensive Reading in L2. Ph.D thesis, Victoria University of Wellington, Wellington, New Zealand. Retrieved from http://researcharchive.vuw.ac.nz//handle/10063/1749

COVID-19 creates a positive path for online education. (2020, May 19). Muscat Daily. Retrieved from https://muscatdaily.com/Oman/386726/COVID-19-creates-a-positive-path-for-online-education-

Crossley, S. A., Louwerse, M. M., McCarthy, P., \& McNamara, D. S. (2007). A computational analysis of second language reading texts. Modern Language Journal, 91(1), 15-30. https://doi.org/10.1111/j.1540-4781.2007.00507.x

Davison, A (1986). Readability. The situation today. Reading Education Report No. 70. Champaign, IL: Center for the Study of Reading, University of Illinois. Retrieved from http://www.ideals.illinois.edu/bitstream/handle/2142/17739/ctrstreadtechrepv01985i00359_opt.pdf?sequenc $\mathrm{e}=1$

Day, R. R., \& Bamford, J. (1998). Extensive reading in the second language classroom. Cambridge: Cambridge University Press. https://doi.org/10.1177/003368829802900211

Day, R., \& Bamford, J. (2002). Top Ten Principles for Teaching Extensive Reading. Reading in a Foreign Language, 14(2), 136-141.

Eldridge, J., \& Neufeld, S. (2009). The graded reader is dead, long live the electronic reader. The Reading Matrix, 
9(2), 224-244.

Elley, W. B., \& Mangubhai, F. (1983). The impact of reading on second language learning. Reading Research Quarterly, 19, 53-67. https://doi.org/10.2307/747337

Ellis, R. (2010). The Study of Second Language Acquisition. Oxford, UK: Oxford University Press.

English First (EF) English Proficiency Index. (n.d.). Oman. Retrieved from https://www.ef.com/wwpt/epi/regions/middle-east/oman/

English proficiency in Mideast lowest in the world. (2019, Dec 7). Muscat Daily. Retrieved from https://muscatdaily.com/Oman/385513/English-proficiency-inMideast-lowest-in-the-world

Fawzia, A. S., \& Salwa, A. R. (2016). A Closer Look at Extensive Reading in Omani Public Schools: Current Practices and Teachers' Perceptions. English Language Teaching, 9(8), 93-105. https://doi.org/10.5539/elt.v9n8p93

IELTS. (n.d.) Test taker performance 2018. Retrieved from https://www.ielts.org/teaching-and-research/test-taker-performance

Johnson, P. (1981). Effects on reading comprehension of language complexity and cultural background of a text. TESOL Quarterly, 15(2), 169-181. https://doi.org/10.2307/3586408

Krashen, S. (2009). Principles and Practice in Second Language Acquisition. Retrieved from http://www.sdkrashen.com/Principles_and_Practice/index.html

Krishnan, G., Rahim, R. A., Marimuthu, R., Abdullah, R. B., Mohamad, F., \& Jusoff, K. (2009). The Language Learning Benefits of Extensive Reading: Teachers Should Be Good Role Models. English Language Teaching, 2(4), 107-116. https://doi.org/10.5539/elt.v2n4p107

Lituanas, P. M., Jacobs, G. M., \& Renandya, W. A. (2001) An investigation of extensive reading with remedial students in a Philippines secondary school. International Journal of Educational Research, 35, 217-225. https://doi.org/10.1016/S0883-0355(01)00018-0

Macalister, J. (2008) Integrating Extensive Reading into an English for Academic Purpose Program. The Reading Matrix, 8(1), 23-34. Retrieved from http://www.readingmatrix.com/articles/macalister/article.pdf

Marianne, . (2009). What Lies Beneath the Stated Meanings: a Transactional View of Language Learners Making Meaning with Texts. Ph.D thesis, Victoria University of Wellington, Wellington, New Zealand. Retrieved from http://hdl.handle.net/10063/762

May, P. (2004). IELTS Practice Tests. Oxford University Press

Miles, M. B., \& Huberman, A. M. (1994). Qualitative data analysis: An expanded sourcebook (2nd ed.). Thousand Oaks, CA: Sage.

Nagabhand, S., Nation, I. S. P., \& Franken, M. (1993). Can text be too friendly? Reading in a Foreign Language, 9, 895-907. Retrieved from http://www.victoria.ac.nz/lals/about/staff/publications/paul-nation/1993-Nagabhand-Topic-type.pdf

Nation, I. S. P. (2001). Learning vocabulary in another language. Cambridge: Cambridge University Press. https://doi.org/10.1017/CBO9781139524759

National Reading Panel. (2000). Teaching children to read: An evidence-based assessment of the scientific research literature on reading and its implications for reading instruction. Retrieved from http://www.nichd.nih.gov/publications/nrp/report.cfm.

Nell, V. (1988). Lost in a book: The psychology of reading for pleasure. New Haven, CT: Yale University Press. https://doi.org/10.2307/j.ctt1ww3vk3

Neuman, S. B. (2009). The case for multimedia presentations in learning: A theory of synergy. In A. G. Bus \& S. B. Neuman (Eds.), Multimedia and literacy development. Improving achievement for young learners ( $\mathrm{pp}$. 44-56). New York: Routledge

New London Group. (1996). A pedagogy of Multiliteracies: Designing social futures. Harvard Educational Review, 66(1), 60-93. https://doi.org/10.17763/haer.66.1.17370n67v22j160u

Nuttall, C. (1996). Teaching reading skills in a foreign language. London. Heinemann

Oman suspends schools, universities from Sunday. (2020, March 14). Oman Daily Observer. Retrieved from https://www.omanobserver.om/oman-suspends-schools-universities-from-sunday/ 
Rosenblatt, L. M. (1986). The aesthetic transaction. Journal of Aesthetic Education, 20(4), 122-128. https://doi.org/10.2307/3332615

Rosenblatt, L. M. (2005). Making Meaning with Texts. New Hampshire: Heinemann

Seidlhofer, B. (2004). Research perspectives on teaching English as a lingua franca. Annual Review of Applied Linguistics, 24, 209-239. https://doi.org/10.1017/S0267190504000145

Shari, M. (2008). Male Teenagers'Need for Extensive Reading. Paper presented at International Language Conference (ILC), International Islamic University Malaysia, Malaysia. Retrieved from http://www.iium.edu.my/ilc/?download=16-e08.pdf

Simensen, A. M. (1990). Adapted texts: A discussion of some aspects of reference. Reading in a Foreign Language, 6(2), 399-411. Retrieved from http://nflrc.hawaii.edu/rfl/PastIssues/rfl62simensen.pdf

Smith, F. (1985). Reading without nonsense (2nd ed.). New York: Teachers College Press.

Sun, Y. C. (2003). Extensive reading online: An overview and evaluation. Journal of Computer Assisted Learning, 19, 438-446. https://doi.org/10.1046/j.0266-4909.2003.00048.x

Susser, B., \& Robb, T. (1990). EFL Extensive Reading Instruction: Research and Procedure. JALT Journal, 12(2). Retrieved from http://www.cc.kyoto-su.ac.jp/ trobb/sussrobb.html

Syahro, S. S. (2009). VOA Special English as a tool for intensive reading program. Master's project paper, Faculty of Education, $\mathrm{U}$ of Malaya.

Syahro, S. S. (2011). VOA Special English as a Tool for Intensive Reading Program. In M. K. K. Abdullah, T. K. Eng, N. Othman \& T. W. Keong (Eds.), 20th MELTA International Conference 2011: English Language Education and Global Learning: Policy, Practice, Performance (pp. 134-148). 30 May-1 June 2011. Kuala Terengganu, Malaysia: Malaysian English Language Teaching Association

Templer, B. (2009). A two-tier model for a more simplified and sustainable English as an international language. Journal for Critical Education Policy Studies, 7(2), 187-216.

Thompson, R., \& McIlnay, M. (2019). Nobody wants to read anymore! Using a multimodal approach to make literature engaging. Children's Literature in English Language Education, 7(1), 61.

Voice of America Learning English. (n.d.). Retrieved from https://learningenglish.voanews.com/

Wallace, C. (1988). Learning to read in a multicultural society: The social context of second language literacy. New York: Prentice Hall.

Walz, J. (2001). Reading hypertext: Higher-level processes. Canadian Modern Language Review, 57, 590-606. https://doi.org/10.3138/cmlr.57.4.590

Welch, R. A. (1997). Introducing Extensive Reading. The Language Teacher, 21(5), 51-52. Retrieved from http://assets.cambridge.org/97805210/16513/sample/9780521016513ws.pdf

Zhang, J. (2009). On the Construction of Resource-Library-Based Network Teaching Platform of English Extensive Reading. ICNDS, 285-288. https://doi.org/10.1109/ICNDS.2009.77

\section{Copyrights}

Copyright for this article is retained by the author, with first publication rights granted to the journal.

This is an open-access article distributed under the terms and conditions of the Creative Commons Attribution license (http://creativecommons.org/licenses/by/4.0/). 